\title{
Index to Volume 54
}

\author{
INDEX TO AUTHORS AND TITLES
}

Aguilar Jr., Filomeno V. "Experiencing Transcendence: Filipino Conversion Narratives and the Localization of Pentecostal-Charismatic Christianity." 54:585-627.

Anderson, Benedict R. O'Gorman.

"Forms of Consciousness in $\mathrm{El}$ Filibusterismo." 54:315-56.

Anderson, James N. and Nobuhiko Fuwa. "Filipina Encounters with Japan: Stories Beyond the Stereotype from a Pangasinan Barangay." 54:111-41.

"The Burgos Manifiesto: The Authentic Text and Its Genuine Author." John N. Schumacher, S.J. 54:153304.

"Catholics Rich in Spirit: El Shaddai's Modern Engagements." Katharine

L. Wiegele. 54: 495-520.

"Charismatic Christians: Genuinely Religious, Genuinely Modern." Christl Kessler. 54:560-84.
"Chronicles of a Monastic: Three Books by Sr. Teresa Joseph Constantino, O.C.D." Raul P. Lejano. 54:473-80.

Coroza, Michael M. Review of Bullets and Roses: The Poetry of Amado V. Hernandez, a Bilingual Edition, by Cirilo F. Bautista. 54:487-90.

"Doña Luisa Gonzaga de León (18051843), First Filipino Woman Author: Introductory Notes." Luciano P. R. Santiago. 54:357-80.

"Experiencing Transcendence: Filipino Conversion Narratives and the Localization of Pentecostal-Charismatic Christianity." Filomeno V. Aguilar Jr. 54:585-627.

"Filipina Encounters with Japan: Stories Beyond the Stereotype from a Pangasinan Barangay." Nobuhiko Fuwa and James N. Anderson. 54:111-41. 
"Forms of Consciousness in El Filibusterismo." Benedict R. O'Gorman Anderson. 54:315-56.

Fuwa, Nobuhiko and James N. Anderson. "Filipina Encounters with Japan: Stories Beyond the Stereotype from a Pangasinan Barangay." 54:111-41.

"The Gift of Nationalism: Comments on Fr. John Schumacher's 'The Burgos Manifiesto." Vicente L. Rafael. 54:305-11.

Guillermo, Ramon. "Rizal's 'tagalische Verskunst' Essay: A Case of SelfTranslation and Pseudotranslation." 54:452-72.

"Isabelo de los Reyes and the Philippine Contemporaries of La Solidaridad." Megan C. Thomas. 54: $381-411$.

Kessler, Christl. "Charismatic Christians: Genuinely Religious, Genuinely Modern." 54:560-84.

"The Kyoto Protocol's Clean Development Mechanism: Prospects for Japan-Philippines Partnership." Rosalina Palanca-Tan. 54: 41-81.

Lejano, Raul P. "Chronicles of a Monastic: Three Books by Sr. Teresa Joseph Constantino, O.C.D." 54: 473-80.

. Review of Cry, Beloved Motber Cburch, Rejoice; Reacbing Out to God in the 21st Century; and Personalizing Russia: Even By Those Who Know Her Little But Love Her Much, by Teresa
Joseph Constantino, O.C.D. 54: 473-80.

"Mining and the Environment in the Philippines: The Limits on Civil Society in a Weak State." David Wurfel. 54:3-40.

"The New 'American' Houses in the Colonial Philippines and the Rise of the Urban Filipino Elite." Kiyoko Yamaguchi. 54:412-51.

Palanca-Tan, Rosalina. "The Kyoto Protocol's Clean Development Mechanism: Prospects for JapanPhilippines Partnership." 54: 41-81.

Paredes, Oona Thommes. "True Believers: Higaunon and Manobo Evangelical Protestant Conversion in Historical and Anthropological Perspective." 54:521-59.

"Philippine Postcolonial Studies: Essays on Language and Literature." Maria Teresa Tinio. 54: 142-48.

Pilario, Daniel Franklin, C.M. Review of Mystic Wanderers in the Land of Perpetual Departures, by Karl M. Gaspar. 54:481-85.

Rafael, Vicente L. "The Gift of Nationalism: Comments on Fr. John Schumacher's 'The Burgos Manifiesto."' 54:305-11.

Rixhon, Gerard. Review of Ukeil: $V i$ sual Arts of the Sulu Archipelago, by Ligaya Fernando-Amilbangsa. 54:485-87.

“Rizal's 'tagalische Verskunst' Essay: A 
Case of Self-Translation and Pseudotranslation." Ramon Guillermo. 54:452-72.

Santiago, Luciano P. R. "Doña Luisa Gonzaga de León (1805-1843), First Filipino Woman Author: Introductory Notes." 54:357-80.

Schumacher, S.J., John N. "The Burgos Manifiesto: The Authentic Text and Its Genuine Author." 54:153-304.

Thomas, Megan C. "Isabelo de los Reyes and the Philippine Contemporaries of La Solidaridad." 54:381411.

Tinio, Maria Teresa. "Philippine Postcolonial Studies: Essays on Language and Literature." 54:142-48.

"True Believers: Higaunon and Manobo Evangelical Protestant Conversion in Historical and An- thropological Perspective." Oona Thommes Paredes. 54:521-59.

"The Wakaoji Abduction and the

Roppongi Property Sale: Perspectives from the Philippine Press." Helen Yu-Rivera. 54:82-110.

Wiegele, Katharine L. "Catholics Rich in Spirit: El Shaddai's Modern Engagements." 54: 495-520

Wurfel, David. "Mining and the Environment in the Philippines: The Limits on Civil Society in a Weak State." 54:3-40.

Yamaguchi, Kiyoko. "The New 'American' Houses in the Colonial Philippines and the Rise of the Urban Filipino Elite." 54:412-51.

Yu-Rivera, Helen. "The Wakaoji Abduction and the Roppongi Property Sale: Perspectives from the Philippine Press." 54:82-110.

\section{BOOKS REVIEWED}

Bullets and Roses: The Poetry of Amado $V$. Hernandez, a Bilingual Edition, by Cirilo F. Bautista. Reviewed by Michael Coroza. 54:487-90.

Cry, Beloved Mother Church, Rejoice, by Susan Jose / Teresa Joseph Constantino, O.C.D. Reviewed by Raul P. Lejano. 54:473-80.

Mystic Wanderers in the Land of Perpetual Departures, by Karl M. Gaspar. Reviewed by Daniel Franklin Pilario,

\section{C.M. 54:481-85.}

Personalizing Russia: Even By Those Who Know Her Little But Love Her Much, by Teresa Joseph Constantino, O.C.D. Reviewed by Raul P. Lejano. 54:473-80.

Pbilippine Postcolonial Studies: Essays on Language and Literature, edited by Cristina Pantoja Hidalgo and Priscelina Patajo-Legasto. Reviewed by Ma. Teresa Tinio. 54:142-48. 
Reaching Out to God in the 21st Century, by Josefina Constantino [Teresa Joseph Constantino, O.C.D.]. Re- viewed by Raul P. Lejano. 54:473-80. Ukkil: Viswal Arts of the Sulu Archipelago, by Ligaya Fernando-Amilbangsa. Reviewed by Gerard Rixhon. 54:485-87.

\section{PIJI.MAST \\ phiptim, or of THE phit, trethes

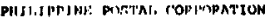 \\ Nat ional Capital Rouion \\ Liwasang Manifacio \\ 1000 Manila}

Pormit Mo.: old

Date granted: 25 Auguat 1953

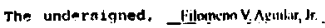

editor / busineun manager /

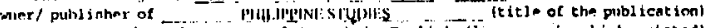

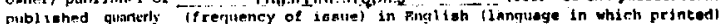
publ rehed gut a

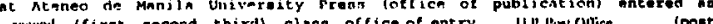

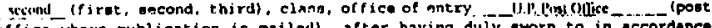

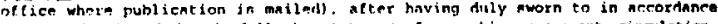

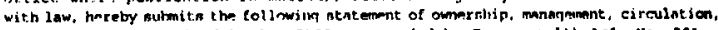
etc., which da required by Act 2580 as anended by Commonwealth Aet. Wo. 201 .

\begin{tabular}{|c|c|c|}
\hline & & Addrenges \\
\hline biditor & 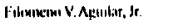 & 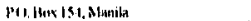 \\
\hline Cwner & 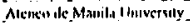 & 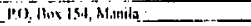 \\
\hline $\begin{array}{l}\text { Publinker } \\
\text { Prininar } \\
\text { office of publicetion }\end{array}$ & 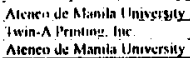 & 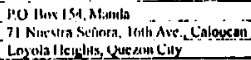 \\
\hline
\end{tabular}

It punljeation in ounnd by corporation, etockholdere owning one percent or more of the cotel amount of otock:

Gondholdera, mortigages or othat nocurity holdere owning one percent or more of the tolnt amount of nocurity:

II cane of denily publiention, avernqe number of coples printad and circulated of each zanus during the preceding month of

1. Sinnt 10 piel nubacribar

2. Sent to othera than paid subscribera

Total:

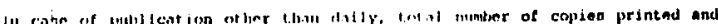

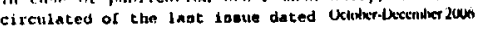

1. Sent to paid muberibero

2. Sint to othern than pali auberribers

3. Retained for tuture oales
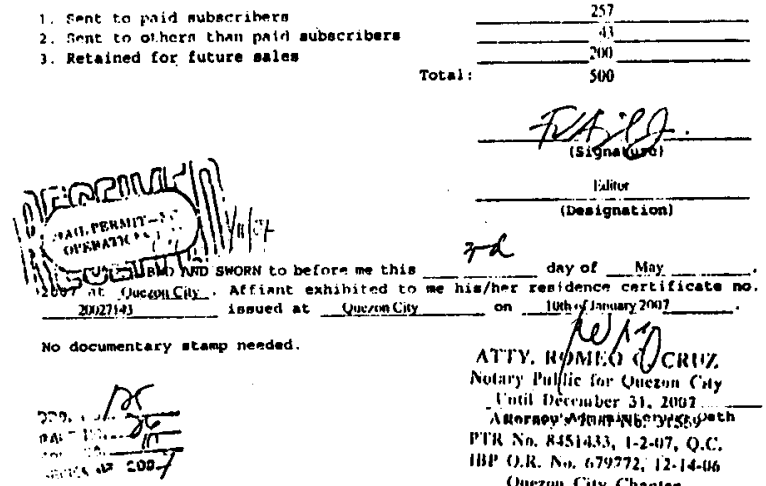

lidings

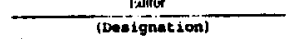

$3 x$

day of Mny idenes certificecte no.

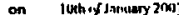
Affinnt exhibited to l'util Derruber 31. 2007 .

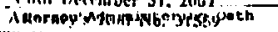
P'I'K Nin. A+51 4.3.3, 1-2.t57, O.C. IH! (1).R. N.1. 6.79372, 12.14-146 Uuezon City Chapter 